\title{
MEMENTO MORI
}

\section{Carmen González Huguet}

"...y no balle cosa en que poner los ojos que no fuera recuerdo de la muerte"

QUEVEDO

Es la sombra que viene,

La garra preparada

Para el golpe certero,

La mirada en alerta

Que busca, sigue, acecha.

Nada se escapa al ojo

Implacable y absorto.

Nada al cruel arrebato.

Cuando la furia cae

Rasgando piel y carne,

$Y$ la vida se escapa,

$Y$ la sangre se amansa,

$Y$ se instala la muerte;

Entonces comprendemos

Que el mayor enemigo,

El más voraz y aleve,

Nos hiere siempre el último

Desde adentro del pecho.
Ya no te creo, ciudad, el paraíso, El eterno jardín donde la dicha enciende

Sus fuegos de San Telmo.

Tampoco te concibo como la cuna de las ilusiones, O el rincón iluminado

Por las luces secretas del deseo.

Caída la venda de los espejismos, Eres tan sólo ese paisaje sórdido Donde rufianes y tahúres

Se tasan mutuamente, Mientras los mismos tiburones Se mastican sin pausa Con sus dientes de oro.

La araña teje su tela, indiferente, Mientras tanto. 
Tarde o temprano,

Cualquiera ha de caer.

\section{III}

No tengo escapatoria.

Me disecciona el tiempo, me

[diluye,

Disuelve esta mirada, estas dos manos,

Esta cruel suavidad de mis

[mejillas,

La acuosa transparencia de mis

[ojos.

Erosiona el delirio que alimenta

La fuerza de mis pasos.

Me condena a este tedio sin

[raíces,

A la profunda y constante

[frustración.

Estoy presa en el fondo de esta cárcel de huesos,

Donde nervios y músculos me sostienen y ahogan.

En este nido soy

El polluelo del pájaro.

La única salida

Es echar a volar.

\section{IV}

iAh, si me disolviera!

Si me volviera de agua,

Si hecha gota en tu río
Pudiera hallar el mar.

Si derramada toda

Me bebieras entera.

Si alimentara tu hambre

Y escaldara tu sed.

Si líquida y extensa

Encontrara en tu cuerpo

Forma definitiva.

Si así, ya confundida

Contigo, te saciara.

Si convertida en río

Fuera un sorbo de sed.

\section{V}

Baja el pálido párpado sobre el ojo cortado.

Baja la antigua lágrima sobre el día encendido

Con su hoguera cegando

Niñas de labios verdes

$\mathrm{Y}$ abriendo el vientre henchido de madres insepultas.

¿Quién dijo esa mentira odiosa

como la dulce dictadura

de la maestra infame

que día y noche nos miente la

bondad de las naranjas,

de la regla de tres

y de Dios padre

siempre tan maternal, austero y $\tan$ lejano? 
Vivo en un país triste, Encandilado por el humo, Alucinando con supercherías [azucaradas

Como patria, fútbol, revolución o muerte, donde los ángeles olvidan en las manos de los niños las navajas de noche para que deliciosamente se [acuchillen, mientras el pobrecito poeta siga repitiendo en voz alta el gran poema del largo tragaespadas, y nuevos novelistas instalen en la muerte al mártir para siempre.

La paz, esa dolida Farsa, esa dulce

Mentira, ese puñal
Clavado con banderas

$\mathrm{Y}$ con himnos de fondo.

Esa utopía mil veces postergada.

Esa hipoteca que pesa

Sobre todos nosotros,

Engordando los réditos

De la próxima guerra.

\section{VII}

Pasó el guardia vendiendo su

Y el policía ofreciendo su [picana,

[garrote,

Y el guerrillero regateando su [fusil,

Y el rompehuelgas alquilando sus [infamias, Y el demagogo usufructuando a [su mamá.

Pero en la caja, Cerrada firmemente, Sólo quedó una pluma Ensangrentada. 


\title{
VERSOS DE LA CAPITANA
}

\author{
Mario Noel Rodríguez
}

Metida sin descanso en las brasas de mis brazos, jurando sentar las bases de locura alterna, labor en la que los pájaros danzan hasta perder la cabeza, mientras en el estercolero de la memoria busco, peleo, divago, saco de la nada vientos.

Metida en la ordinaria crucifixión de las tardes, paloma que rasca con la voluntad de encontrarme, de encontrarme concentrado en su corazón de pegaso, en su vientre que revela edenes a manos repletas.

Metida en mí, en la secreta avalancha, te nombro capitana de mares, aguas en las que Neruda buscaba hasta el suicidio versos para sus más musas 